\title{
HUBUNGAN ANTARA PRESTASI BELAJAR DENGAN SKABIES PADA SANTRIWATI DI PONDOK PESANTREN AN-NUR 2 PUTRI AL-MURTADLO, MALANG
}

\author{
Dhelya Widasmara $^{* \varpi}$, Panji Sananta** ${ }^{* *}$ Virginia Rosa Tamadi***
}

\begin{abstract}
Abstrak
Skabies adalah penyakit kulit menular yang disebabkan oleh parasit atau tungau Sarcoptes scabiei. Tungau Sarcoptes scabiei ini berukuran sangat kecil dan hanya bisa dilihat dengan bantuan alat mikroskop. Penyebaran penyakit skabies ini bisa dengan kontak langsung ataupun secara tidak langsung melalui sprei, pakaian, handuk, dan lainnya. Penyakit skabies lebih sering menyerang komunitas atau daerah dengan padat penduduk seperti pesantren, asrama, lembaga pemasyarakatan yang kebersihan diri dan lingkungannya kurang baik. Tujuan penelitian ini untuk mengetahui demografi di pondok pesantren An-Nur 2 Putri Al-Murtadlo Bululawang, Malang dan untuk mengetahui hubungan antara skabies dengan prestasi belajar santriwati. Jenis penelitian ini adalah cross-sectional dengan jumlah sampel sebanyak 60 orang di antaranya 30 golongan skabies negatif dan 30 lainnya skabies positif. Pemilihan sampel dengan teknik purpose sampling berdasarkan kriteria inklusi yang telah ditetapkan. Data diperoleh dengan kuisioner dan nilai rapor. Hasil penelitian menunjukkan terdapat hubungan yang bermakna, uji Chi-square menunjukan nilai rapor sebelum dan sesudah 6 bulan terakhir dengan $p$-value $=0,000$, frekuensi mendapatkan 10 besar di kelas selama tinggal di pesantren didapatkan $p$-value $=0,001$, hasil analisis nilai rapor dengan skabies menunjukkan $p$-value $=0,000$. Kesimpulannya terdapat pengaruh antara prestasi belajar dengan skabies.

Kata kunci: skabies, Sarcoptes scabei, prestasi belajar.

\section{RELANTIONSHIP BETWEEN LEARNING ACHIEVEMENT WITH SCABIES IN FEMALE STUDENTS AT GIRLS ISLAMIC BOARDING SCHOOL AN-NUR 2 AL-MURTADLO, MALANG}

\begin{abstract}
Scabies is an infectious skin disease caused by a parasite or mite Sarcoptes scabiei. They are very small and can only be seen using a microscope. The spread of scabies can be by direct contact or indirectly through bed linen, clothes, towels, and others. Scabies more often attacks communities or areas with densely populated areas such as boarding schools, dormitories, prisons with poor personal hygiene and environment. The purpose of this study was to determine the demographics of Girls Islamic Boarding School An-Nur 2 Al-Murtadlo in Bululawang, Malang and to determine the relationship between scabies and student achievement. This type of research is cross-sectional with a sample of 60 people including 30 groups of negative scabies and 30 other positive scabies. Sample selection with purpose sampling technique based on predetermined inclusion criteria. The data obtained by questionnaire and report card grades. The results showed a significant relationship, Chisquare test shows the report before and after the last 6 months with $p$-value $=0.000$, the frequency of getting the top 10 in class while living in boarding schools obtained $p$-value $=0.001$, and then the results of analysis report cards with scabies show the significance $p$-value $=0.000$. The conclusion, there is an influence between learning achievement with scabies.
\end{abstract}

Keywords: scabies, Sarcoptes scabei, learning achievement.

* Departemen Dermatologi \& Venereologi, Fakultas Kedokteran, Universitas Brawijaya

** Departemen IImu Bedah Ortopaedi, Fakultas Kedokteran, Universitas Brawijaya

*** Program Studi Sarjana Kedokteran (S1), Fakultas Kedokteran, Universitas Brawijaya

\section{E-mail: dhelyawidasmara@ub.ac.id}




\section{Pendahuluan}

Skabies (kudis) merupakan penyakit kulit yang disebabkan parasit tungau Sarcoptes scabiei. ${ }^{1}$ Prevalensi penyakit skabies di Indonesia cukup banyak ditemukan di asrama tentara, pondok pesantren dan penjara. ${ }^{2}$ Skabies adalah penyakit infeksi parasit pada kulit yang ditularkan secara langsung seperti kontak kulit dengan kulit, dan secara tidak langsung seperti bertukar pakaian, handuk, selimut, sprei, alat ibadah. ${ }^{3}$

Menurut WHO 2009, skabies banyak ditemukan pada semua negara tropis, prevalensinya berkisar hingga $7-35 \%$ dari populasi umum dan insiden skabies tertinggi ditemukan pada kelompok anak berusia 1-14 tahun sebesar $51,5 \%$. Prevalensi di Indonesia ditemukan pada tahun 2009 sebesar 4,9\%$12,95 \%$ dan data terakhir yang ditemukan kejadian skabies di Indonesia tahun 2013 sebesar 3,9-6\%. Di kota Malang menurut Riskesdas (2013, dikutip dalam penelitian Setyaningrum 2016) menyatakan bahwa prevalensi skabies di Ponpes Malang Raya sebanyak $61 \%$, ditemukan prevalensi paling tinggi di Kabupaten Malang sebesar 48,6\%, sedangkan di Kota Batu paling rendah sebesar $12,4 \%{ }^{4}$

Skabies sering mengenai para santri yang tinggal di pondok pesantren, karena pesantren merupakan hunian padat yang kondisi kebersihannya kurang terjaga dan lembab, serta sanitasi yang buruk mengakibatkan angka prevalensinya tinggi. ${ }^{3}$ Dengan tingginya prevalensi skabies yang menyerang area pesantren tentu hal tersebut akan berdampak besar pada kehidupan para santri antara lain santri tidak bisa berkonsentrasi, sehingga mengakibatkan penurunan prestasi belajar para santri. Hal ini sesuai dengan data tiga pesantren di kabupaten Aceh Besar pada tahun 2007, didapatkan $15,5 \%$ santri yang terkena infeksi skabies nilai rapor menurun bahkan di antaranya ada yang tidak naik kelas dan tidak lulus ujian. ${ }^{5}$

Manifestasi klinis utama dari skabies adalah gatal yang sangat hebat pada malam hari. ${ }^{6}$ Gatal yang terjadi dikarenakan adanya iritasi dan menyebabkan reaksi hipersensitivitas yang diakibatkan oleh akumulasi bahan sisa sekresi tungau serta kotoran (skibala) ketika membuat terowongan. Reaksi hipersensitivitas yang terkait adalah tipe I dan tipe IV. ${ }^{7}$ Manifestasi kulit lainnya ditemukan nodul, papul, vesikel, krusta yang timbul pada ujung terowongan. ${ }^{8}$

Skabies dipengaruhi oleh beberapa faktor risiko seperti kebersihan lingkungan yang buruk, tingkat ekonomi yang rendah, status pendidikan, hunian lingkungan padat, usia, jenis kelamin dan kontak dengan penderita skabies secara langsung maupun tidak langsung. ${ }^{9}$

Diagnosis klinis bisa ditegakkan jika ditemukan 2 dari 4 tanda cardinal sign yang meliputi: (1). Gatal terutama pada malam hari, (2). Gatal dan ditemukan lesi khas dipredileksi tertentu, (3). Ditemukan gejala yang sama pada anggota keluarga atau orang terdekat, (4). Pada pemeriksaan mikroskopis ditemukan tungau dalam berbagai fase atau adanya skibala (kotoran). 8 Pemeriksaan tambahan untuk mendukung diagnosis klinis dan menemukan tungau atau skibala yaitu: a). Mengambil tungau dengan jarum; b). Uji kerok kulit; c). Tetes tinta pada terowongan; d). Uji tetrasiklin; e). Biopsi irisan; f). Dermoskopi. 9

Peningkatan aktivitas skabies pada malam hari yang menyebabkan sensasi gatal hebat tentu akan mengganggu kenyamanan yang berujung menyebabkan gangguan tidur pada penderita, sehingga penderita akan mengalami gejala kurang tidur seperti lelah, lesu, tidak bersemangat, kurang berkonsentrasi, sakit kepala, dan sering menguap., 8,10 Penurunan konsentrasi akan berdampak pada penurunan prestasi belajar. ${ }^{11}$ 
Melihat pentingnya penyakit skabies pada siswa pesantren maka dilakukan penelitian yang bertujuan untuk mengetahui demografi pada santriwati yang menderita skabies di Pondok Pesantren An-Nur 2 Putri Al-Murtadlo, Bululawang, Malang dan mengetahui hubungan skabies dengan prestasi belajar para santriwati di Pondok Pesantren An-Nur 2 Putri AlMurtadlo, Bululawang.

\section{Bahan dan Metode}

Penelitian ini merupakan penelitian analitic observational dengan pendekatan crosssectional, yaitu suatu penelitian untuk mempelajari dinamika korelasi dengan cara pendekatan observasi atau pengumpulan data sekaligus pada suatu saat (point, time and approach). Penelitian ini telah mendapatkan persetujuan dari Komite Etik dengan nomor etik 106/EC/KEPK/04/2018. Etika penelitian dalam penelitian ini mencangkup informed consent (lembar persetujuan), confidently (kerahasiaan), dan protection from discomfort. Penelitian ini dilakukan selama 3 bulan pada bulan April 2018 sampai Juni 2018. Penelitian ini dilakukan di Pondok Pesantren An-nur 2 Putri Al-Murtadlo JL. Raya Bululawang, Bululawang, Malang, Jawa Timur.

Kriteria inklusi penelitian antara lain: 1). Santriwati bersedia mengikuti penelitian dan walinya telah menandatangi informed consent ; 2). Santriwati berusia di bawah 18 tahun; 3). Santriwati bersedia mengisi kuisioner; 4). Santriwati tidak terkena penyakit kulit sebelum masuk pondok pesantren; 5). Santriwati yang memiliki salinan Ujian Tengah Semester (UTS) atau Ujian Akhir Semester (UAS). Kriteria eksklusi penelitian yaitu santriwati yang memiliki penyakit kulit lainnya (panu, kudis, dermatitis kontak alergi/ iritan). Untuk mengetahui jumlah sampel digunakan rumus berikut :

$$
\mathrm{n}=\frac{\left\{z_{1-g / 2} \sqrt{\mathrm{P}_{0}\left(1-\mathrm{P}_{0}\right)}+z_{1 \cdot \beta} \sqrt{\mathrm{P}_{\mathrm{a}}\left(1-\mathrm{P}_{\mathrm{a}}\right)}\right\}^{2}}{\left(\mathrm{P}_{\mathrm{a}}-\mathrm{P}_{0}\right)^{2}}
$$

Jumlah sampel diperoleh sebanyak 26 orang, agar lebih representatif, maka jumlah minimal sampel tadi ditambah 10\%, Sehingga jumlah sampel menjadi 29 orang. Teknik yang digunakan untuk pengambilan sampel adalah teknik purposive sampling. Sampel diambil tidak secara acak dan ditentukan oleh peneliti sendiri.

Variabel bebas penelitian adalah sc kabies dengan skala pengukuran nominal dan variabel tergantung adalah prestasi belajar dengan skala pengukuran ordinal nilai 61-80 dengan kategori memuaskan dan 81-100 dengan kategori sangat memuaskan. Cara pengumpulan data yaitu: 1). Peneliti melakukan anamnesis serta observasi yang dibantu oleh dokter spesialis kulit yang terkait; 2). Dokter speliasis kulit menegakkan diagnosis skabies terhadap subjek; 3). Menanyakan identitas dan memberikan informed consent terhadap subjek; 4). Subjek yang positif skabies dan telah mengisi informed consent dilakukan wawancara menggunakan kuisioner persepsi yang terkait dengan prestasi belajar subjek; 5). Peneliti mengambil data salinan nilai UTS/UAS tahun 2017-2018 subjek; 6). Analisis data yaitu uji statistik dengan variabel bebas dan variabel terikat berupa kategorik dan tidak berpasangan, sehingga dilakukan uji Chi square untuk mencari hubungan antara prestasi belajar dengan skabies; 7). Uji signifikan antara data yang diobservasi dengan data yang diharapkan dilakukan dengan batas kemaknaan $(\alpha=0,05)$ yang artinya apabila diperoleh $p<\alpha$, berarti ada hubungan yang signifikan antara variabel bebas dengan variabel terikat dan bila nilai $p>a$, berarti tidak ada hubungan signifikan antara variabel bebas dengan variabel terikat. 
Hasil

Hasil penelitian yang telah dilakukan di Pondok Pesantren An-nur 2 Putri Al-murtadlo, Bululawang, Malang sejak bulan Mei hingga Juli 2018, didapatkan 60 sampel penelitian skabies berdasarkan hasil yang memenuhi kriteria inklusi, dimana 30 dengan skabies negatif dan 30 dengan skabies positif. Responden merupakan santriwati Pondok Pesantren An-Nur 2 Putri Al-Murtadlo, Bululawang, Malang.

Berdasarkan hasil perbandingan usia antara kelompok dengan scabies positif dan negatif pada santriwati di Pondok Pesantren An-Nur 2 Putri Al-Murtadlo, didapatkan dari total sampel 60 orang, sebanyak 30 orang pada kelompok skabies poitif, pada umur 12 tahun sebanyak 8 orang $(13,3 \%)$ dan umur 13 tahun sebanyak 6 orang $(10,0 \%)$. Pada umur 14 tahun sebanyak 4 orang $(5,0 \%)$, umur 15 tahun sebanyak 6 orang $(10,0 \%)$, umur 16 tahun sebanyak 5 orang $(8,3 \%)$, dan umur 17 tahun sebanyak 2 orang $(3,3 \%)$. Sedangkan pada kelompok skabies negatif didapatkan jumlah sampel 30 orang, pada umur 12 tahun sebanyak 8 orang $(13,3 \%)$, umur 13 tahun sebanyak 7 orang $(11,7 \%)$, umur 14 tahun sebanyak 5 orang $(8,3 \%)$, umur 15 tahun sebanyak 5 orang $(8,3 \%)$, umur 16 tahun sebanyak 5 orang $(8,3 \%)$, sedangkan pada umur 17 tahun sebanyak 0 orang (0\%). Pada umur tidak berpengaruh signifikan terhadap skabies (Tabel 1).

Berdasarkan hasil perbandingan kelas antara kelompok dengan skabies positif dan negatif pada santriwati di Pondok Pesantren AnNur 2 Putri, Al-Murtadlo, diketahui bahwa pada kelompok skabies positif didapatkan sampel sebanyak 30 , pada kelas 7 sebanyak 6 orang $(10,0 \%)$, kelas 8 sebanyak 8 orang $(13,3 \%)$, kelas 9 sebanyak 3 orang $(5,0 \%)$, kelas 10 sebanyak 4 orang $(6,7 \%)$, kelas 11 sebanyak 6 orang $(10,0 \%)$, dan pada kelas 12 sebanyak 3 orang $(5,0 \%)$. Pada kelompok skabies negatif didapatkan sampel sebanyak 30 orang, pada kelas 7 sebanyak 5 orang $(8,3 \%)$, kelas 8 sebanyak 10 orang $(16,7 \%)$, kelas 9 sebanyak 6 orang $(10,0 \%)$, kelas 10 sebanyak 3 orang $(5,0 \%)$, kelas 11 sebanyak 6 orang $(10,0 \%)$, dan pada kelas 12 sebanyak 0 orang $(0 \%)$.

Berdasarkan hasil penelitian, diketahui dari 60 santriwati Pondok Pesantren An-Nur 2 Putri Al-Murtadlo, sebanyak 21 orang $(35 \%)$ mempunyai nilai hasil belajar antara 66-80 dan mempunyai prestasi belajar yang baik, dan 39 orang $(65,0 \%)$ lainnya mempunyai nilai hasil belajar antara 81-100 yang tergolong mempunyai prestasi belajar yang sangat baik (Gambar 1).

Tabel 1. Demografi berdasarkan umur pada santriwati di Pondok Pesantren An-Nur 2 Putri Al- Murtadlo, Bululawang, Malang

\begin{tabular}{cccc}
\hline Umur (tahun) & \multicolumn{2}{c}{ Kelompok } & Total (\%) \\
\cline { 2 - 3 } & Skabies Positif (\%) & Skabies Negatif $(\%)$ & \\
\hline 12 & $8(13,3 \%)$ & $8(13,3 \%)$ & $16(26,7 \%)$ \\
13 & $6(10,0 \%)$ & $7(11,7 \%)$ & $13(21,7 \%)$ \\
14 & $3(5,0 \%)$ & $5(8,3 \%)$ & $8(13,3 \%)$ \\
15 & $6(10,0 \%)$ & $5(8,3 \%)$ & $11(18,3 \%)$ \\
16 & $5(8,3 \%)$ & $5(8,3 \%)$ & $10(16,7 \%)$ \\
17 & $2(3,3 \%)$ & $0(0 \%)$ & $2(3,3 \%)$ \\
Total & $30(50,0 \%)$ & $30(50,0 \%)$ & $60(100,0 \%)$ \\
\hline
\end{tabular}


Dari 30 orang siswa yang menderita skabies positif, sebanyak 5 orang menunjukkan hasil ujian selama 6 bulan terakhir yang tidak memuaskan, 16 orang tergolong mempunyai hasil ujian rata-rata, dan 9 orang lainnya tergolong mempunyai hasil ujian yang memuaskan. Sedangkan dari 30 orang siswa yang tidak menderita skabies, ada 1 orang yang mempunyai hasil ujian selama 6 bulan terakhir yang rata-rata, 16 orang tergolong mempunyai hasil ujian yang memuaskan, dan 13 orang lainnya tergolong mempunyai hasil ujian yang sangat memuaskan

Santriwati di Pondok Pesantren An-Nur 2 Putri Al-Murtadlo, Bululawang, Malang yang tidak mengalami skabies (scabies negative) akan cenderung mempunyai prestasi belajar yang lebih baik daripada siswa yang menderita scabies (scabies positive) dengan rentang antara 2,37 kali sampai dengan 30,46 kali lebih berpeluang mempunyai prestasi belajar yang lebih baik. (selang kepercayaan 95\% odds ratio $[(2,37),(30,46)]$.

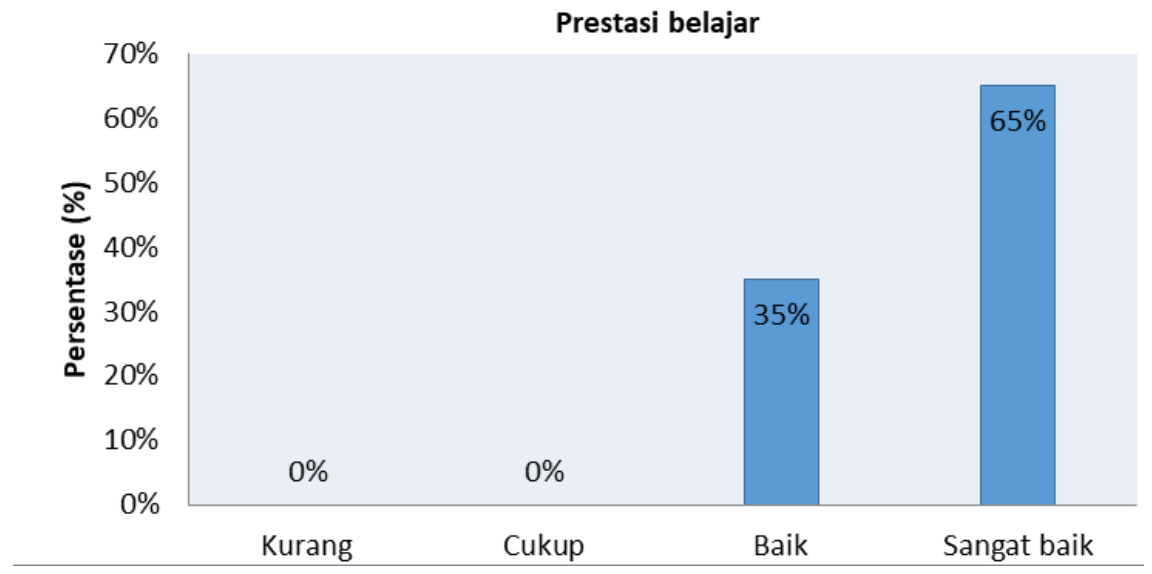

Gambar 1. Distribusi frekuensi prestasi belajar santriwati di Pondok Pesantren An-Nur 2 Putri Al-Murtadlo, Bululawang, Malang.

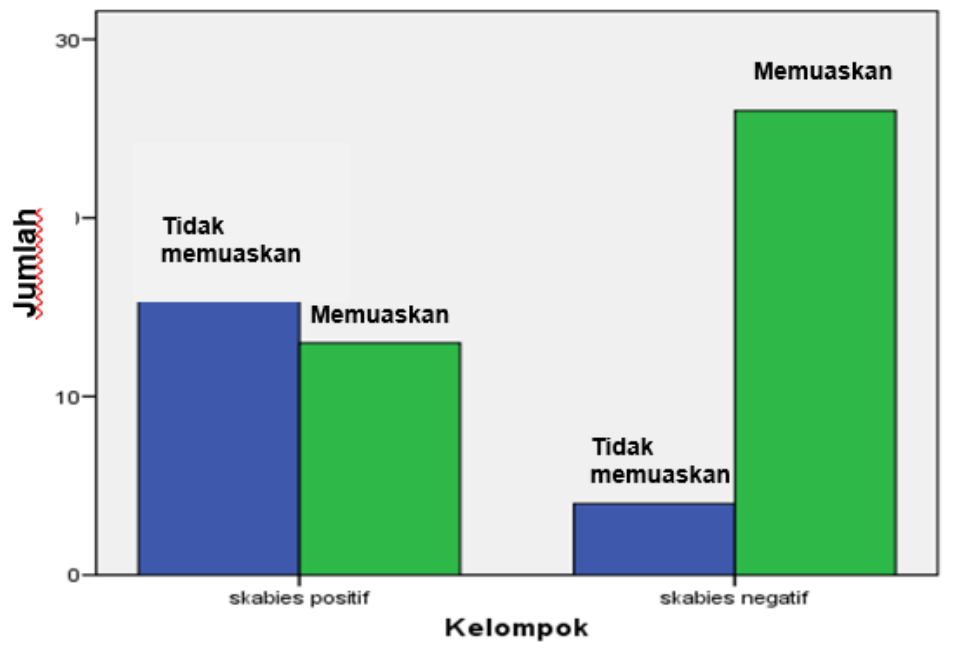

Gambar 2. Prestasi belajar santri pada kelompok skabies positif dan negatif. 


\section{Pembahasan}

Penelitian ini bertujuan untuk mengetahui hubungan skabies dengan prestasi belajar pada santriwati kelas 7, 8, dan 9 tingkat Madrasah Tsanawiyah (MTs) dan santriwati kelas 10, 11, dan 12 tingkat Madrasah Aliyah (MA) yang tinggal di Pondok Pesantren An-Nur 2 Putri AlMutadlo yang telah memenuhi kriteria. Tahapan diagnosis dilakukan terhadap 60 subjek penelitian dan didapatkan prevalensi skabies $50 \%$. Insiden dan prevalensi cukup tinggi pada sebagian santriwati terkena skabies, sejalan dengan hasil penelitian Ratnasari (2013) bahwa prevalensi skabies di Pondok Pesantren di Jakarta Timur sebesar 51,6 \%. Pada penelitian ini usia responden berada di antara usia 12 sampai 17 tahun. Rata-rata usia responden pada penelitian ini baik dengan skabies negatif maupun skabies positif adalah 14 tahun.

Ratnasari (2014) dalam penelitiannya tentang prevalensi dan epidemiologi mengungkapkan bahwa prevalensi skabies lebih rendah pada santri yang memiliki tingkat pendidikan MAN daripada MTS. ${ }^{12}$ Menurut hasil penelitian kasus skabies pada santriwati di Pondok Pesantren An-Nur 2 Putri Al-Murtadlo, Malang sebagaian besar pada santriwati kelas 8 tingkat MTs atau santriwati berumur 12 tahun sebesar $13,3 \%$.

Dari hasil penelitian ini, diperoleh informasi bahwa dari 60 santriwati Pondok Pesantren AnNur 2 Putri Al-Murtadlo, Bululawang, Malang yang menjadi responden, ada sebanyak 21 orang (35\%) yang mempunyai nilai hasil belajar antara 66-80 dan tergolong mempunyai prestasi belajar yang baik, dan 39 orang $(65,0 \%)$ lainnya mempunyai nilai hasil belajar antara 81-100 dan tergolong mempunyai prestasi belajar yang sangat baik. Berdasarkan hasil penelitian yang telah dilakukan didapatkan pada hasil kuisioner rata-rata nilai 6 bulan terakhir diketahui bahwa dari 30 orang siswa yang menderita skabies positif, ada sebanyak 5 orang yang mempunyai hasil ujian selama 6 bulan terakhir yang tidak memuaskan, 16 orang tergolong mempunyai hasil ujian yang pas rata-rata, dan 9 orang lainnya tergolong mempunyai hasil ujian yang memuaskan. Namun, dari 30 orang siswa yang tidak menderita skabies, ada 1 orang yang mempunyai hasil ujian selama 6 bulan terakhir yang pas rata-rata, 16 orang tergolong mempunyai hasil ujian yang memuaskan, dan 13 orang lainnya tergolong mempunyai hasil ujian yang sangat memuaskan. Dapat disimpulkan dari penelitian ini bahwa responden yang menderita skabies lebih berisiko mengalami penurunan prestasi belajar. Hasil penelitian ini menunjukkan nilai signifikansi $0,000(p<0,5)$, sehingga ada hubungan yang signifikan antara skabies dengan hasil ujian 6 bulan terakhir saat menderita skabies, sehingga dapat disimpulkan bahwa ada hubungan yang signifikan antara hasil ujian selama 6 bulan terakhir dengan skabies.

Pada penelitian ini juga membahas hasil belajar menggunakan kuisioner, ditemukan pada santriwati yang menderita skabies, 26 orang mendapatkan hasil yang kurang dan 4 orang mendapatkan hasil yang baik, sementara pada santriwati yang tidak menderita skabies ditemukan 6 orang mendapat hasil belajar yang kurang dan 28 orang mendapatkan hasil belajar yang baik. Hasil uji Chi-Square menunjukkan nilai signifikansi sebesar $0,000(p<0,05)$ yang artinya terdapat hubungan yang signifikan dengan skabies dan didukung oleh hasil uji korelasi Spearman, hasil tersebut menunjukkan koefisien korelasi sebesar 0,668 dengan nilai signifikansi sebesar $0,000(p<0,05)$, yang menunjukkan ada hubungan yang signifikan dengan hasil belajar. Arah korelasi yang positif dapat diartikan bahwa santriwati yang tidak mengalami skabies akan cenderung mempunyai hasil belajar yang lebih baik daripada santriwati yang menderita skabies. 
Pada penelitian ini membahas rata-rata nilai Ujian Akhir Semester (UAS) sebelum 6 bulan terakhir, diketahui bahwa dari 30 santriwati yang menderita skabies sebanyak 3 orang yang mempunyai nilai hasil ujian tidak memuaskan, 14 orang tergolong mempunyai hasil ujian yang pas rata-rata, dan 13 orang tergolong mempunyai hasil yang memuaskan. Sementara, dari 30 orang santriwati yang tidak menderita skabies, ada sebanyak 14 orang yang mempunyai nilai hasil ujian memuaskan dan 16 orang lainnya tergolong mempunyai nilai hasil ujian yang memuaskan. Pada santri yang menderita skabies akan mengalami gatal yang hebat terutama pada malam hari. Gatal terutama dirasakan pada bagian sela-sela jari tangan, permukaan depan pergelangan tangan, sekitar siku, bawah ketiak, pinggang, areola mammae dan alat kelamin. Hal tersebut menimbulkan ketidaknyamanan dan menurunkan produktivitas belajar santri.9,13

Pada penelitian ini juga membahas peringkat santriwati selama tinggal di pesantren. Dari total sampel 60 santriwati, 30 santriwati yang menderita positif skabies didapatkan sebanyak 11 santriwati yang tidak pernah mendapatkan peringkat 10 besar selama tinggal di pesantren, 13 santriwati yang lain menyatakan jarang mendapatkan peringkat 10 besar, dan 6 santriwati mengaku sering mendapatkan peringkat 10 besar. Sementara, dari 30 santriwati yang tidak menderita skabies, ada 2 santriwati yang tidak mendapatkan peringkat 10 besar selama tinggal di pesantren, 8 santriwati lainnya menyatakan jarang mendapatkan peringkat 10 besar, dan 12 santriwati mengaku sering mendapatkan peringkat 10 besar. Berdasarkan hasil uji Chi-Square menunjukkan nilai signifikansi 0,001 ( $p<0,5)$, sehingga dapat disimpulkan bahwa terdapat hubungan yang signifikan antara frekuensi mendapatkan peringkat 10 besar selama tinggal di pesantren dengan skabies. Hal tersebut berkolerasi dengan uji Spearman yang menunjukkan koefisien kolerasi sebesar 0,532 dengan nilai signifikasi $0,000(p<0,05)$, maka dapat diartikan bahwa terdapat juga hubungan yang signifikan antara frekuensi mendapatkan peringkat 10 besar selama tinggal di pesantren dengan skabies. Mengacu pada arah kolerasi yang positif dapat diartikan bahwa santriwati di Pondok Pesantren An-Nur 2 Putri Al-Murtadlo, yang mengalami skabies (scabies positive) akan cenderung kesulitan mendapatkan peringkat 10 besar selama tinggal di pesantren dibandingkan santriwati yang tidak menderita skabies (scabies negative).

Penurunan prestasi belajar santri tidak hanya dipengaruhi oleh faktor fisiologis, namun juga dipengaruhi oleh faktor lainnya, seperti faktor individu dan faktor eskternal. Pada faktor individu, gaya belajar dan kemampuan verbal dapat menggambarkan kemampuan akademik dimana siswa akan memiliki prestasi yang baik di sekolah, jika sebelumnya siswa belajar terlebih dahulu serta ada dorongan motivasi dari dalam diri maupun orang tua ${ }^{14}$ Pada faktor eksternal, lingkungan belajar dan gaya/pendekatan yang digunakan siswa dalam belajar yang baik akan meningkatkan prestasi belajar siswa, begitu pula sebaliknya. Selain itu, fasilitas belajar dan profesionalisme pendidik yang sesuai dalam menunjang proses pembelajaran dan pengajaran juga dapat mempengaruhi prestasi belajar siswa. 8,15

Ada beberapa keterbatasan pada penelitian ini yaitu tidak mengukur tingkat konsentrasi santriwati dengan cara yang lebih spesifik. Selain itu, sampel yang digunakan tidak ada santri laki-laki untuk membedakan apakah ada perbedaan yang spesifik antara laki-laki dan perempuan terhadap skabies. Serta, tidak adanya nilai rapor sebelum menderita skabies, sehingga tidak dapat memperlihatkan secara keseluruhan prestasi santriwati. 


\section{Kesimpulan}

Berdasarkan hasil penelitian ini dapat disimpulkan bahwa skabies dapat menyerang santriwati di Pondok Pesantren An-Nur 2 Putri Al-Murtadlo, Malang pada berbagai tingkatan kelas dan golongan umur, serta terdapat hubungan signifikan antara prestasi belajar dengan skabies pada santriwati di Pondok Pesantren An-Nur 2 Putri Al-Murtadlo, Malang.

\section{Daftar Pustaka}

1. Boediardja SA. Dermatitis Atopik. IImu Penyakit Kulit dan Kelamin, Edisi ke-7. Jakarta: Badan Penerbit FKUI. 2015.

2. Soemirat J. Kesehatan Lingkungan. Yogyakarta: Gadjah Mada University Press. 2011.

3. Djuanda A. IImu Penyakit Kulit dan Kelamin Jilid III. Jakarta : Fakultas Kedokteran Universitas Indonesia. 2010.

4. Setyaningrum YI. Prevalensi dan Analisis Penyebab Scabies di Pondok Pesantren Malang Raya sebagai Materi Pengembangan Buku Saku Tentang Scabies dan Upaya Pencegahannya. Seminar Nasional Pendidikan Biologi FKIP UNS. 2016.

5. Muzakir. Faktor yang Berhubungan dengan Penyakit Skabies di Pesantren di Kabupaten Aceh Besar Tahun 2007 [Thesis]. Medan: Universitas Sumatera Utara. 2008.

6. Patel $T$, Ishiuji $Y, \&$ Yosipovitch $G$. Nocturnal Itch: Why Do We Itch at Night? PMID. 2007; 87(4):295-8.
7. Rakhmawati D, dkk. Laporan Kasus: Crusted Scabies.Pertemuan IImiah Tahunan XII PERDOSKI. Solo. 2012.

8. Sudarsono. Pengaruh Skabies Terhadap Prestasi Belajar Santri di Sebuah Pesantren di Kota Medan. MDVI. 2012; 39(3):108-12.

9. Handoko RP. Skabies dalam Ilmu Penyakit Kulit dan Kelamin. Edisi Ke-6. Jakarta: Badan Penerbit FKUI. 2010. HIm.122-125.

10. Hidayat A. Pengantar Kebutuhan Dasar Manusia. Jakarta: Salemba Medika. 2006.

11. Astuti E. Faktor-faktor yang Mempengaruhi Prestasi Belajar Mata Pelajaran Pengetahuan Sosial-Ekonomi pada Siswa Kelas VIII SMP Negeri 2 Padamara, Kab. Purbalingga Tahun Pelajaran 2005/2006 [Tesis]. Semarang: Universitas Negeri Semarang. 2007.

12. Ratnasari AF \& Sungkar S. Prevalensi Skabies dan Faktor-faktor yang Berhubungan di Pesantren X , Jakarta Timur. MJI. 2014; 2 (1):7-12.

13. Wolff K, Goldsmith LA, Katz SI, Gilchrest BA, Paller AS, Leffel DJ. Fitzpatrick's Dermatology in General Medicine. $7^{\text {th }}$ Edition. New York: Mc Graw Hill. 2008.

14. Lizar EN. Hubungan Infeksi Soil Transmitted Helminth (STH) dengan Tingkat Kecerdasan dan Prestasi Akademik pada Siswa SD Negeri 1 Krawangsari Kecamatan Natar. [Skripsi]. Bandar Lampung: Universitas Lampung. 2016.

15. Latipah E. Strategi Self Regulated Learning dan Prestasi Belajar. Psi. 2010; 37(1):11029. 